\title{
ASSESSMENT OF CUSTOMER SATISFACTION ON SERVICE QUALITY AT SAIGON - HANOI COMMERCIAL JOINT STOCK BANK (SHB)
}

\author{
Tran Minh Hieu ${ }^{1}$, Nguyen Hoang Anh $^{2}$
}

\begin{abstract}
This study applied the SERVQUAL scale of Parasuraman et al. and the scale of previous research models to measure the quality of Saigon - Hanoi Commercial Joint-Stock Bank. The study used Cronbach's Alpha reliability test method and exploratory factor analysis (EFA) to verify and evaluate the scale conducted with a sample size of $n=215$ respondents are customers who use the services of the bank. The research results serve as a basis for Saigon - Hanoi Commercial Joint-Stock Bank to know the factors of service quality that affect satisfaction, the relationship between service quality and satisfaction, level of customer evaluation of these factors, from which an appropriate strategy is carried out to improve customer satisfaction in the future.
\end{abstract}

Keywords: customer satisfaction, Saigon Hanoi Comercial Joint Stock Bank (SHB), service quality.

\section{INTRODUCTION}

The development of a nation is always influenced by the economy. The trend of globalization is increasingly strong, and if Vietnam wants to develop, Viet Nam must integrate into the world economy. The development of modern technology and the trend of industrialization and modernization takes place not only in the fields of economy, finance, and production but also in services, including banking services. The bank world is facing many risks such as the competition of domestic banks, the increasingly fierce competition of foreign banks, and also has to meet the needs of customers.

\footnotetext{
${ }^{1,2}$ An Giang University, Viet Nam National University Ho Chi Minh City, Viet Nam

Email: tmhieu@agu.edu.vn

Received date: $15^{\text {th }}$ October 2020; Revised date: $9^{\text {th }}$ January 2021; Accepted date: $20^{\text {th }}$ January 2021
}

Meeting the needs of customers, retaining old customers, and increasing the number of new ones is one of the factors determining the success of any bank. In order to do this, many commercial banks have implemented many different solutions, including increasing the quality of service to maximize customer satisfaction.

To get the trust of customers, Saigon - Hanoi Commercial Joint Stock Bank (SHB) has been gradually building and providing diverse products and services to all customers with the highest quality.

Assessing the quality of SHB's service is to help the bank identify the factors affecting the quality of service provided and utilizing research to find out the customer's perceived information on the quality of service, and explain consumer satisfaction with this service, and the perceived quality of the service. In order to make adjustments to improve customer satisfaction with this service, and to enhance the competitive advantage for SHB, this is a study that brings necessity.

\section{LITERATURE REVIEW}

The SERVQUAL scale is widely used in all types of services in general, but using this scale in each type of service needs to be studied and adjusted according to the specific characteristics of the industry. To match the retail service industry, it relied on qualitative research, service theory and SERVQUAL to develop the Retail Service Quality Scale [1] (RSQS). The scale consists of 28 observed variables of which 17 are from the SERVQUAL scale and the remaining 11 variables are drawn from qualitative research. According to the RSQS, the five basic components of retail store service quality are: tangible vehicles - store premises and display; Reliability: stores keep and fulfill their promises; Service staff: The service staff is polite, ready 
to help and create trust for customers; Complaints handling: Store staff capable of handling returns, customer problems and complaints; and Store Policies: Policies for goods quality, parking, opening hours, payment cards. RSQS has been used in many studies to measure the quality of different types of retail services such as grocery stores, supermarkets across Europe.

According to Soyoung Kim and Byoungho Jin, Conducted a study with US and Korean customers for discount stores [2]. The results show that customer perceptions of service quality differ in these two countries. Another study on service quality of supermarket and electronics retail stores [3]. Research shows that RSQS is more suitable in the retail environment where goods are more focused like supermarkets, while SERVPERF will be more suitable in retail when service becomes more important.

In addition, RSQS developed in the US for applicability in India. RSQS has five dimensions and six sub-dimensions and has been found appropriate in a variety of settings - across different countries such as South Africa and Singapore and across a variety of store types such as supermarkets, department stores, and hyper stores. The five dimensions - Physical Aspects, Reliability, Personal Interaction, Problem Solving, and Policy - are believed to capture distinct though correlated aspects of retail service. Each of the first three dimensions has two sub-dimensions. These six sub-dimensions, also called the firstorder factors, are labelled as Appearance, Convenience, Promises, Doingit-Right, Inspiring Confidence, and Courteousness/Helpfulness [4]. And improving the quality of retail banking services at Viet Nam Export Import Commercial Joint Stock Bank [5], research results show that there are 3 factors affecting the quality of retail banking services: reliability, empathy and responsiveness. Based on these, it has been proposed that there are 31 solutions to improve the above 3 factors, in order to improve the quality of retail banking services. At the Bank for Investment and Development of Vietnam (BIDV), research results show that there are 5 factors affecting the quality of retail banking services: tangible, sympathetic, trustworthy, empathic and responsive. Based on the research results, the author has proposed solutions to improve the above 5 factors to improve the quality of retail banking services at BIDV [6].

\section{THEORY}

\section{A. Concept of service}

Due to the diverse and intangible nature of the service, researchers have not yet come up with a unified definition of the service concept. Therefore, there are many different views on services, some of the main concepts and definitions of services are as follows:

According to Parasuraman, service has four important characteristics, greatly influencing the design of effective service operation programs: Intangibility, Heterogeneity, Perishability and Inseparability [7].

According to Kotler and Armstrong, service is any action or benefit that one party can provide to another, which is essentially intangible and provides no ownership at all [8].

Service is an operational process that includes non-existent factors, resolving suppliercustomer relationships or customer property without changing ownership. Products and services may be within or beyond the scope of physical products [9].

\section{B. Service quality}

According to Levesque \& McDougall service quality is a customer decision based on actual experience with the product or service, measured based on customer requirements, which may or may not be stated. Conscious or simply perceptive, purely subjective or professional, and always representing a dynamic goal in a competitive market [10].

Thongsamak proposed two components of service quality: the first is the technical quality, what the customer receives; the second is the quality of functionality, explaining how the service is provided [11].

Parasuraman et al. argued that service quality is the distance between customer expectations, and their perception when using the service. The above definition of Parasuraman is accepted by many scientists and businesses, widely used in research as well as practical business [12], [7]. 


\section{Customer satisfaction}

1) Define: According to Oliver, customer satisfaction is an emotional response, the entire perception of customers to service providers based on the difference between what they receive compared to previous expectations [13].

Customer satisfaction is the perceived state of a customer to a service provider after using it [10]. Satisfaction is a state in which what customers need, want, and expect in a product or service package to be satisfied or exceed satisfaction, resulting in a purchase of valid goods and the value of word of mouth.

Kotler stated that satisfaction is determined on the basis of a comparison between the results received from the service and the customer expectations based on the following three levels: If the results received are less than expected wait, the customer will feel dissatisfied, if the result is as expected, the customer will be satisfied, and if the results are than expected, customers will be very satisfied and enjoy the service [13].

2) The relationship between service quality and customer satisfaction: Customer satisfaction and service quality are two separate but interrelated structures. Service quality is an objective and cognitive concept, whilst satisfaction is a combination of subjective components, based on feelings and emotions [11].

Service quality is the most important factor affecting customer satisfaction [14]. If a service provider grants customers quality products that meet their needs, that business has initially made customer satisfaction.

Zeithalm \& Bitner argued that customer satisfaction is affected by many factors such as product quality, service quality, price, situational factors, and personal factors [15].

Service quality and satisfaction are two different concepts but closely related in service research [16].

\section{The service quality gap model of Parasura- man et al}

Customers' expectations for service quality are at a distance from their perception of that service quality. Parasuraman et al. proposed the following five service quality gap model [15] [7]:
- The first gap is the discrepancy between the managers' perceptions and customers' expectations.

- The second gap is created when the supplier conveys the supplier's perceived expectations to the quality criteria that meet the customer's expectations.

- When the result of service provision is below the standard level, the third distance appears.

- The fourth gap is the discrepancy between the information informed to the customer and the service delivery.

- The fifth gap appears when there is a difference between the expected quality from the customer and the quality they have felt.

This model has the advantage of covering all aspects of the service, but it has the disadvantage of being difficult to evaluate, measure and analyze. Moreover, this model is theoretical, so there may be many components that are not discriminatory, so in 1988, Parasuraman made many adjustments and came to the conclusion that the service quality consisted of five components.

Parasuraman built the final SERVQUAL scale to evaluate service quality including 22 variables of 5 components to measure the expected quality and perceived service shown as follows: reliability, responsiveness, assurance, empathy and tangible facilities [12].

However, the use of SERVQUAL needs to be adjusted to suit the different types of services and markets that the study is aiming at, so the number of observed variables and content will change accordingly.

Based on the service quality model of Parasuraman et al. to measure customer satisfaction in the banking sector, the measurement model uses 5 service quality factors as a basis. Reliability, Assurance, Empathy, Tangibles, and Responsibility [12]. (Appendix 1).

\section{E. Research hypotheses}

H1: Reliability is positively related to satisfaction, which is the higher the reliability of the service is, the higher the satisfaction of service quality is and vice versa.

$\mathrm{H} 2$ : Assurance is positively related to satisfaction, which is the higher the service capacity of 


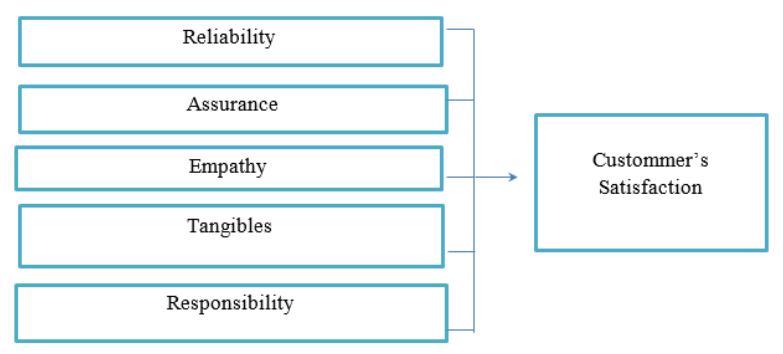

Fig. 1: Research model

the customer service is, the higher the satisfaction of service quality is and vice versa.

H3: Empathy is positively related to satisfaction, which is the higher the value of customer service is, the higher the satisfaction of service quality is and vice versa.

H4: Tangibles is positively related to satisfaction, meaning the higher the tangible means of service are rated by customers, the higher the satisfaction of service quality and vice versa.

H5: Responsibility is positively related to satisfaction, which is the higher the satisfaction of customer service is, the higher the satisfaction of service quality is and vice versa.

\section{RESULTS AND DISCUSSION}

The questionnaire was completed by customers who are using the services of SHB, with a nonprobability sampling method with a convenient sampling form with a sample size of 215 . The results collected 215 questionnaires, of which 15 were unqualified and were discarded.

\section{A. Reliability test results with Cronbach's Alpha}

After completing the scale test using Cronbach's Alpha coefficient, the number of observed variables remained at 25 variables, and 5 independent variables (Reliability, Responsibility, Empathy, Assurance, and Tangibility). The dependent variable is satisfaction.

\section{B. Results of Exploratory Factor Analysis (EFA)}

1) The results of EFA for the service quality factors scale: After the four discovering factor analysis, the analysis results show that the KMO coefficient is very high $(0.5<\mathrm{KMO}=0.853<$
Table 1: Summary results of Cronbach's Alpha coefficients

\begin{tabular}{|c|l|c|c|}
\hline No & Scale & $\begin{array}{c}\text { Number } \\
\text { of } \\
\text { observed } \\
\text { variables }\end{array}$ & $\begin{array}{c}\text { Cronbach's } \\
\text { Alpha }\end{array}$ \\
\hline $\mathbf{I}$ & Reliability & 6 & 0.723 \\
\hline $\mathbf{2}$ & Responsibility & 6 & 0.774 \\
\hline $\mathbf{3}$ & Empathy & 5 & 0.875 \\
\hline $\mathbf{4}$ & Assurance & 4 & 0.840 \\
\hline $\mathbf{5}$ & Tangibility & 5 & 0.816 \\
\hline $\mathbf{6}$ & Satisfaction & 5 & 0.797 \\
\hline
\end{tabular}

1.0), showing that the factor analysis results are suitable for the research data.

Bartlett's Test has Sig. is $0.000<0.05$, showing that the results of factor analysis ensure a statistically significant level.

At Eigenvalues is $1.173>1$, the factor analysis (EFA) extracted 4 factors from 16 observed variables with a total variance extracted of $66.522 \%$ $>50 \%$ (satisfactory), which means 4 cores. The above factor extracted $66.522 \%$ of the variance of the observed variables.

EFA 1. Based on the Rotated Component Matrix, it shows the observed variables RES5 (with load coefficients respectively 0.587 and 0.430 ), RES2 (with load coefficients of 0.458 and 0.479 , respectively), TAN5 (with load coefficients respectively). 0.415 and 0.465 respectively), the difference in factor load factor is less than 0.3 should be disqualified (Appendix 2).

EFA 2. Based on the Rotated Component Matrix, it shows the observed variables REL5 (load coefficients of 0.616 and 0.400 respectively), REL3 (load coefficients respectively 0.430 and 0.622), REL6 (load coefficients respectively 0.407 and 0.478 ) and have the difference load factor is less than 0.3 , so it is rejected, and the variable REL4 has a factor load factor of less than 0.4, so it is also disqualified (Appendix 3).

EFA 3. Based on the Rotated Component Matrix, it shows the observed variables RES4 (with load coefficients respectively 0,456 and 0.611 ), REL1 (with load coefficients respectively 0.422 and 0.581 ) and has the difference coefficient load factor less than 0.3 should be disqualified, and variable REL2 has a factor load factor of less 
than 0.4, so it is also disqualified (Appendix 4).

Thus, after EFA eliminates unsatisfactory variables, the scales are met. The results of exploratory factor analysis (EFA) have 4 groups of factors extracted from the model.

$\mathrm{KMO}$ and Bartlett's tests in factor analysis showed that KMO coefficient is $0.875>0.5$ with sig significance level $=0.000$. Thus, the factors qualify for EFA factor analysis.

Based on the results of the sample matrix, the observed variables have factor load factor $>$ 0.3 , so it is eligible for factor analysis. Based on the results of the total variance explained at the level of Eigenvalues greater than 1, the analysis table extracted four groups of factors from the 16 observed variables with extracted variance of $60.24 \%$ satisfactory because it is greater than 50

After 4 times of EFA, there are 4 groups of factors extracted from the model.

- The first group of factors includes 5 observed variables EMP5, EMP1, EMP2, EMP4 and EMP3.

- The second group of factors includes 4 observed variables ASS2, ASS1, ASS4, and ASS3.

- The third group of factors includes 4 observed variables TAN2, TAN3, TAN1, and TAN4.

- The fourth group of factors includes $3 \mathrm{ob}-$ served variables RES1, RES3, and RES6.

\section{The results of EFA for the satisfaction scale}

KMO and Bartlett's tests in factor analysis for satisfaction show that KMO coefficient is 0.781 greater than 0.5 , sig significance level is $0.000<0.05$. Therefore, the basis of variables is correlated with each other and suitable for EFA analysis.

Eigenvalue coefficient of components greater than 1 , with extract variance, is $55.263 \%$ greater than $50 \%$, so it meets the requirements.

Factor load factor of observed variables is greater than 0.4 , so it meets the requirement in factor analysis.

\section{Regression analysis results}

The coefficient of determination $\mathrm{R}^{2}$ has been shown to be a non-decreasing function by the number of independent variables included in the model (5 variables). However, the model is often not suitable with actual data as the $\mathrm{R}^{2}$ value (0.480) shows. In this situation, $\mathrm{R}^{2}$ is considered as an optimistic estimate of the model's suitability with data and the adjusted $R^{2}$ from $R^{2}$ is used to better reflect the relevance of the linear regression model multivariate (0.469). Comparing the adjusted $R^{2}$ and $R^{2}$ values show that the adjusted $\mathrm{R}^{2}$ coefficient is 0.469 , which is less than $R^{2}$ (0.480), so using $R^{2}$ adjusted to evaluate the suitability of the model will be safer because it does not add dependence on the magnification deviation of $\mathrm{R}^{2}$, and does not inflate the model relevance. The adjustment coefficient $\mathrm{R}^{2}$ means that $46.9 \%$ of customer satisfaction variation is explained by 4 independent variables EMP, ASS, TAN, RES - while $53.1 \%$ of customer satisfaction variation is solved by factors outside the model.

The results show that all VIF indexes are less than 2, which means the independent variables are not closely related to each other, so the regression model has no multicollinearity.

Testing the hypothesis of the suitability of the model by testing F. shows that the F-test has Sig $=0.000$, proving that the set linear regression model is suitable for the data set as well as the independent variables in the model, which can explain the change of the dependent variable.

The regression weight table is considered because the weight $\beta$ of these variables is statistically significant (Sig. $=0.00<0.05$ ). Therefore, variables EMP, ASS, TAN, RES have effects on the variable SAT.

Thus the linear regression equation is rewritten as follows: $S A T=0.252 A S S+0.244 T A N+$ $0.236 E M P+0.226 R E S$

The regression results show that the independent variables ASS, TAN, EMP and RES having Beta coefficients, respectively, 0.252; 0.244; $0.236 ; 0.226$ all have positive signs, so all variables have the same effect with customer satisfaction on service quality at SHB.

It can be concluded that the suitability of the theoretical model for the data, and hypotheses H1, H2, H3, H4 are accepted. The results show that there are 4 independent variables with significant effects on the dependent variable (sig < 0.05 ). And the remaining 4 factors included in the regression analysis are retained in the model. 
Table 2: Factor rotation matrix in EFA

\begin{tabular}{|l|l|l|l|l|}
\hline \multirow{2}{*}{ Observed variables } & \multicolumn{3}{|c|}{ Factors } \\
\cline { 2 - 5 } & \multicolumn{1}{|c|}{$\mathbf{l}$} & \multicolumn{1}{|c|}{$\mathbf{2}$} & $\mathbf{3}$ & $\mathbf{4}$ \\
\hline EMP5 & 0.810 & & & \\
\hline EMP1 & 0.796 & & & \\
\hline EMP2 & 0.794 & & & \\
\hline EMP4 & 0.782 & & & \\
\hline EMP3 & 0.769 & & & \\
\hline ASS2 & & 0.817 & & \\
\hline ASS1 & & 0.810 & & \\
\hline ASS4 & & 0.750 & & \\
\hline ASS3 & & 0.707 & & \\
\hline TAN2 & & & 0.815 & \\
\hline TAN3 & & & 0.791 & \\
\hline TAN1 & & & 0.764 & \\
\hline TAN4 & & & 0.733 & 0.731 \\
\hline RES1 & & & & 0.711 \\
\hline RES3 & & & & \\
\hline RES6 & & & & \\
\hline
\end{tabular}

Table 3: Results of EFA of customer satisfaction

\begin{tabular}{|c|c|}
\hline Observed variables & Factor \\
\cline { 2 - 2 } & SAT \\
\hline SAT3 & 0.770 \\
\hline SAT1 & 0.763 \\
\hline SAT5 & 0.750 \\
\hline SAT4 & 0.721 \\
\hline SAT2 & 0.712 \\
\hline Eigenvalue & 2.763 \\
\hline AVE (\%) & 55.263 \\
\hline KMO: 0.781 & Sig. 0.000 \\
\hline
\end{tabular}

Table 4: Summary of models

\begin{tabular}{|c|c|c|c|c|}
\hline $\mathbf{R}$ & $\mathbf{R}^{\mathbf{2}}$ & $\begin{array}{c}\mathbf{R}^{\mathbf{2}} \\
\text { adjusted }\end{array}$ & $\begin{array}{c}\text { Std. Error of } \\
\text { the Estimate }\end{array}$ & $\begin{array}{c}\text { Durbin- } \\
\text { Watson }\end{array}$ \\
\hline $0.692^{\mathrm{a}}$ & 0.480 & 0.469 & 0.351 & 1.734 \\
\hline
\end{tabular}

E. Customer satisfaction on service quality at $S H B$

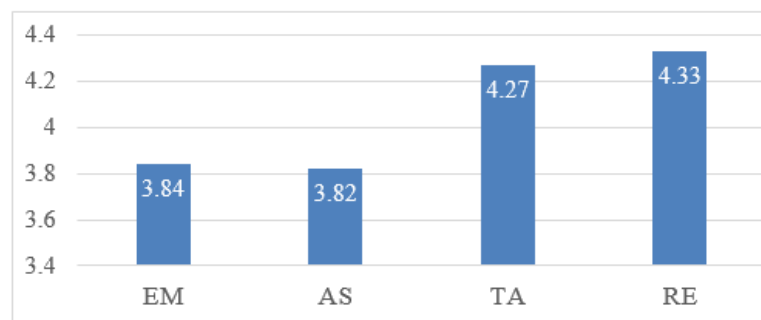

Fig. 2: Customer satisfaction on service quality at SHB

Through Figure 2, customers highly appreciate SHB service quality with an average of 3.84 to 4.33 , of which customers rated the reliability best (average 4.33). This shows that this is a strength of SHB because of the reputation and outstanding service quality. Along with the reliability, the Tangibility, also highly appreciated, and ranked second with an average value of 4.27 , shows that service efficiency is also a strength that SHB 
needs to pay attention to maintain customers' trust. To be ranked the third in customer evaluation is the average empathy of 3.84, which is quite a high number, proving that customers are also very satisfied with the attention and care that SHB's employees distributed. Therefore, the bank needs to have training and remuneration policies for employees to improve customer satisfaction for SHB. Although ranked lowest among the four scales, the assurance vehicle component is rated at a high level (average of 3.82) with modern facilities. This proves that SHB's service quality is relatively good and meets the needs of customers.

\section{CONCLUSION}

In Cronbach's Alpha test results, discovery factor analysis (EFA) results, there are 4 factors remaining in the research model: Empathy, Assurance, Tangibility, and Responsibility.

Based on the regression model, the order can be seen of the strongest and weakest impacts of independent variables on SA-dependent variables: ASS $(0.25)>\operatorname{TAN}(0.244)>\operatorname{EMP}(0.236)$ $>$ RES (0.226).

The results provide information on the actual quality of service of SHB as a basis to help the bank have solutions to improve customer satisfaction in the future.

Through the research results, the author proposes a number of ideas to improve service quality, thereby attracting new customers and importantly, keeping traditional customers because SHB's development orientation is caring for old customers and satisfy new customer needs.

\section{Improve satisfaction with the element of Assurance factor}

The assurance factor has the strongest impact on customer satisfaction $(\beta=0.252)$. Research results show that customers are satisfied with SHB's service capacity at a good average. To further enhance customer satisfaction SHB needs to regularly organize professional and technical training courses for its employees. Staff must always be equipped with the skills, knowledge to serve customers best. SHB needs to arrange job positions according to criteria of right people, right jobs. In addition, in order to improve the employee's working capacity, the management needs to have preferential policies for employees, as well as social welfare policies for employees.

Improve satisfaction with Tangibility factor

The tangible factor has the second strongest impact on customer satisfaction $(\beta=0.244)$. Research results show that customers are satisfied with SHB's tangibility. In particular, spacious facilities are most appreciated - this is considered an advantage of SHB. However, in order to achieve higher customer satisfaction, SHB needs to maintain and focus on investing as well as regularly repairing or upgrading bank facilities and equipment such as shelves. Documents, lighting quality of light systems, air-conditioning systems, elevator systems. Arranging documents scientifically, beautifully, prominently, and having sanitary facilities can help customers in such a way that they are trading in a completely clean, spacious, and dairy environment. Also, the uniformed and polite bank uniform also contributes to customer satisfaction.

\section{Improve satisfaction with the element of Empathy factor}

Empathy is the third strongest factor affecting customer satisfaction $(\beta=0.236)$. But in this regard, SHB has also done quite well, customers feel satisfied with the reasonable working time of the bank. In addition, the factor that customers are not satisfied with is that SHB has not put customer interests first, so SHB's employees need to be more enthusiastic to show customers that the benefits of customers are always the top priority.

Improve satisfaction with the Responsibility factor

Responsibility is the weakest impact on customer satisfaction $(\beta=0.226)$. Research results show that customers are satisfied with SHB's response. Therefore, in addition to the strengths that the bank has to be maintained and enhanced, there are also some factors to consider: SHB should always maintain the staff with a positive attitude, and ready to serve in any case. 


\section{REFERENCES}

[1] Dabholkar P.A. Consumer evaluations of new technology-based self-service operations: an investigation of alternative models. International Journal of Research in Marketing. 1996; 13(1):29-51.

[2] Soyoung Kim, Byoungho Jin. An Evaluation of the Retail Service Quality Scale For U.S. and Korean Customers of Discount Stores. In NA - Advances in Consumer Research Volume 28, eds. Mary C. Gilly, Joan Meyers-Levy, Valdosta. GA : Association for Consumer Research. 2001:169-176.

[3] Mehta S.C., Lalwani A.K., Li Han S. Service quality in retailing: relative efficiency of alternative measurement scales for different product-service environments. International Journal of Retail \& Distribution Management. 2000; 28(2):62-72.

[4] Kaul S. Measuring Retail Service Quality: Examining Applicability of International Research Perspectives in India. Vikalpa. 2007; 32(1):15-26. DOI:10.1177/0256090920070102.

[5] Tran Thi Tram Anh. Improving the quality of retail banking services at Vietnam Export Import Commercial Joint Stock Bank (Nâng cao chất lương dịch vu ngân hàng bán lẻ tại ngân hàng Thương mại cồ phần xuất nhập khẩu Việt Nam) [Master Thesis]. University of Economics Ho Chi Minh City; 2011.

[6] Do Quang Thang. Evaluation of customer satisfaction about the quality of retail banking services in Joint Stock Commercial Bank for Investment and Development of Vietnam at Vung Tau branch (Đánh giá sự hài lòng của khách hàng về chất lương dịch vu ngân hàng bán lẻ tại Ngân hàng Thương mại cổ phần đầu tư và phát triển Việt Nam chi nhánh Vũng Tàu) [Master Thesis]. Ba Ria - Vung Tau University; 2018.
[7] Parasuraman A., Zeithaml V. A., Berry L. L. Servqual: A multiple-item scale for measuring consumer perc. Journal of Retailing. 1988; 64(1):12-40.

[8] Kotler P, Armstrong G. Principle of marketing (14th Ed). In Library of Congress Catalogingin-Publication Data; 2011:1-8.

[9] Luu Van Nghiem. Marketing in service business (Marketing trong kinh doanh dịch vu). Hanoi: Statistical Publishing House; 2001.

[10] Levesque T., McDougall G. H. Determinants of customer satisfaction in retail banking. International Journal of Bank Marketing. 1996; 14(7):12-20.

[11] Thongsamak S. Service quality: Its measurement and relationship with customer satisfaction. Journal of service marketing. 2001; 14(1):9-26

[12] Parasuraman A., Zeithaml V. A., Berry L. L. A conceptual model of service quality and its implications for future research. Journal of Marketing. 1985; 49:41-50.

[13] Oliver R. L. Satisfaction: A Behavioral Perspective on the Consumer. New York: The McGrawHill Companies; 1997.

[14] Kotler. Marketing insights from A to Z: 80 concepts every manager needs to know. John Wiley \& Sons; 2003.

[15] Cronin Jr J. J., Taylor S. A. Measuring service quality: a reexamination and extension. Journal of Marketing. 1992; 56:55-68.

[16] Zeithaml V. A., Bitner M. J., Gremler D. D., Pandit A. Services marketing: Integrating customer focus across the firm; 2000. 


\section{APPENDIX}

\section{Appendix 1: Research Scale}

\begin{tabular}{|c|c|c|c|}
\hline \multicolumn{2}{|c|}{ Factors } & Observed variables & Scale type \\
\hline \multirow{6}{*}{ Reliability } & REL1 & SHB strictly follows its commitments & Liker $1-5$ \\
\hline & REL2 & $\begin{array}{l}\text { SHB care to solve problems for you when facing } \\
\text { difficulties }\end{array}$ & Liker $1-5$ \\
\hline & REL3 & SHB performs the right service right from the start & Liker $1-5$ \\
\hline & REL4 & SHB provides services as committed on time & Liker $1-5$ \\
\hline & REL5 & SHB always keeps its records and books accurate & Liker $1-5$ \\
\hline & REL6 & SHB sends statements regularly and promptly & Liker $1-5$ \\
\hline \multirow{5}{*}{ Empathy } & EMP1 & SHB always gives you special attention & Liker $1-5$ \\
\hline & EMP2 & SHB's working time is convenient for you & Liker $1-5$ \\
\hline & EMP3 & SHB has a support department for you & Liker $1-5$ \\
\hline & EMP4 & SHB puts your interests first & Liker $1-5$ \\
\hline & EMP5 & SHB staff understands your specific needs & Liker $1-5$ \\
\hline \multirow{6}{*}{ Responsibility } & RES1 & Staff often ask you about customer service & Liker $1-5$ \\
\hline & RES2 & Service staff for you quickly & Liker $1-5$ \\
\hline & RES3 & Staff are always happy to help & Liker $1-5$ \\
\hline & RES4 & Staff are ready to respond to your request & Liker $1-5$ \\
\hline & RES5 & SHB has a hotline to serve you $24 / 24$ & Liker $1-5$ \\
\hline & RES6 & SHB has a convenient transaction network for you & Liker $1-5$ \\
\hline \multirow{4}{*}{ Assurance } & ASS1 & Behavior of SHB staff increases your trust & Liker $1-5$ \\
\hline & ASS2 & You feel safe in your dealings with SHB & Liker $1-5$ \\
\hline & ASS3 & SHB staff are always polite to you & Liker $1-5$ \\
\hline & ASS4 & $\begin{array}{l}\text { SHB staff has sufficient professional knowledge to } \\
\text { answer your questions }\end{array}$ & Liker $1-5$ \\
\hline \multirow{5}{*}{ Tangibles } & TAN1 & SHB' $\mathrm{S}$ equipment is modern and attractive & Liker $1-5$ \\
\hline & TAN2 & SHB has spacious facilities & Liker $1-5$ \\
\hline & TAN3 & Professional and impressive staff attire & Liker $1-5$ \\
\hline & TAN4 & $\begin{array}{l}\text { The documents used in the transaction are very well } \\
\text { designed }\end{array}$ & Liker $1-5$ \\
\hline & TAN5 & Convenient transaction booking location for you & Liker $1-5$ \\
\hline \multirow{5}{*}{ Satisfaction } & SAT1 & You feel satisfied with SHB's facilities & Liker $1-5$ \\
\hline & SAT2 & You feel satisfied with SHB's service style & Liker $1-5$ \\
\hline & SAT3 & You feel satisfied with SHB's services & Liker $1-5$ \\
\hline & SAT4 & You will recommend SHB's services to others & Liker $1-5$ \\
\hline & SAT4 & You will continue to use SHB's services in the future & Liker $1-5$ \\
\hline
\end{tabular}


Appendix 2: Rotated Component Matrix EFA -1

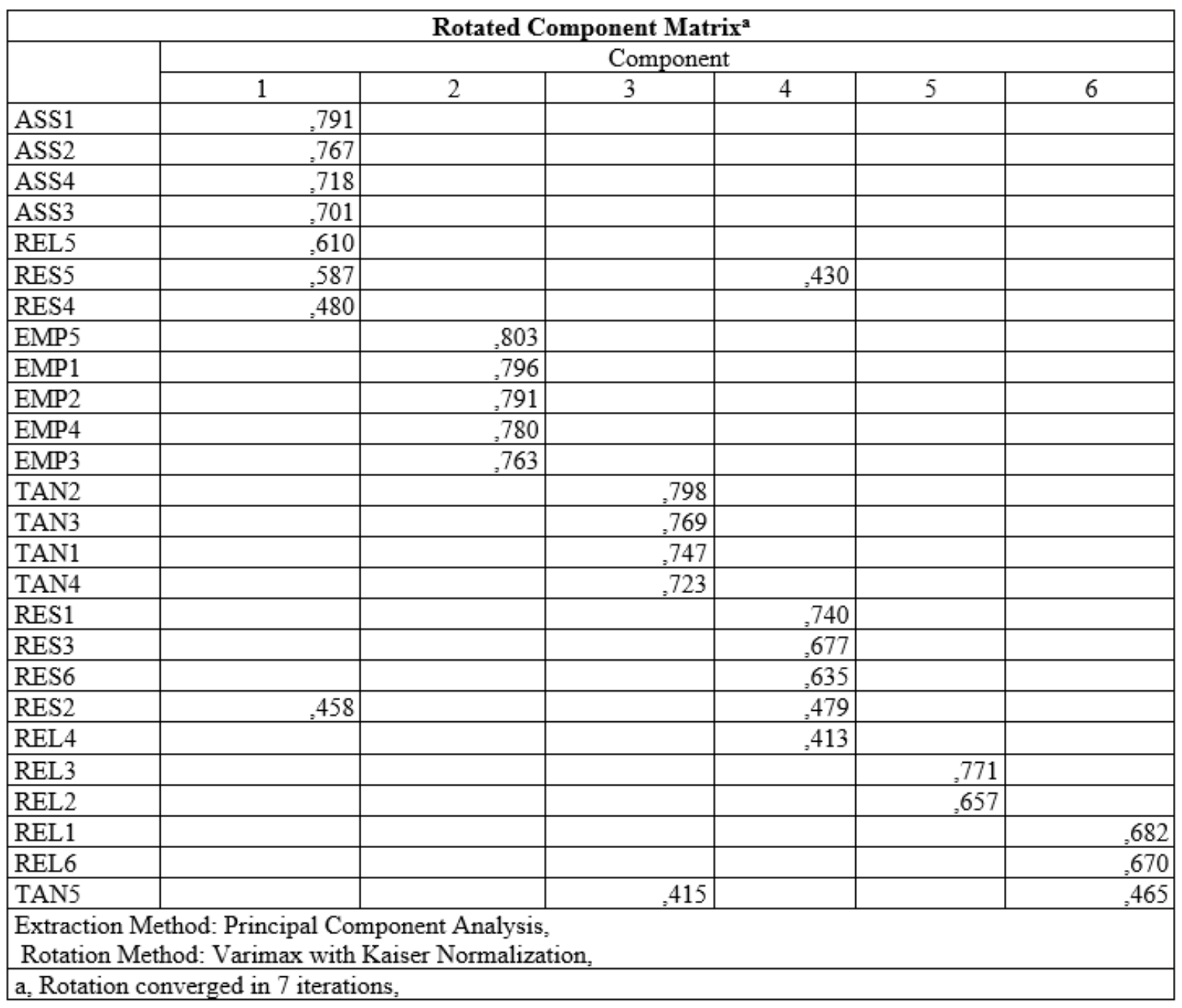




\section{Appendix 3: Rotated Component Matrix EFA -2}

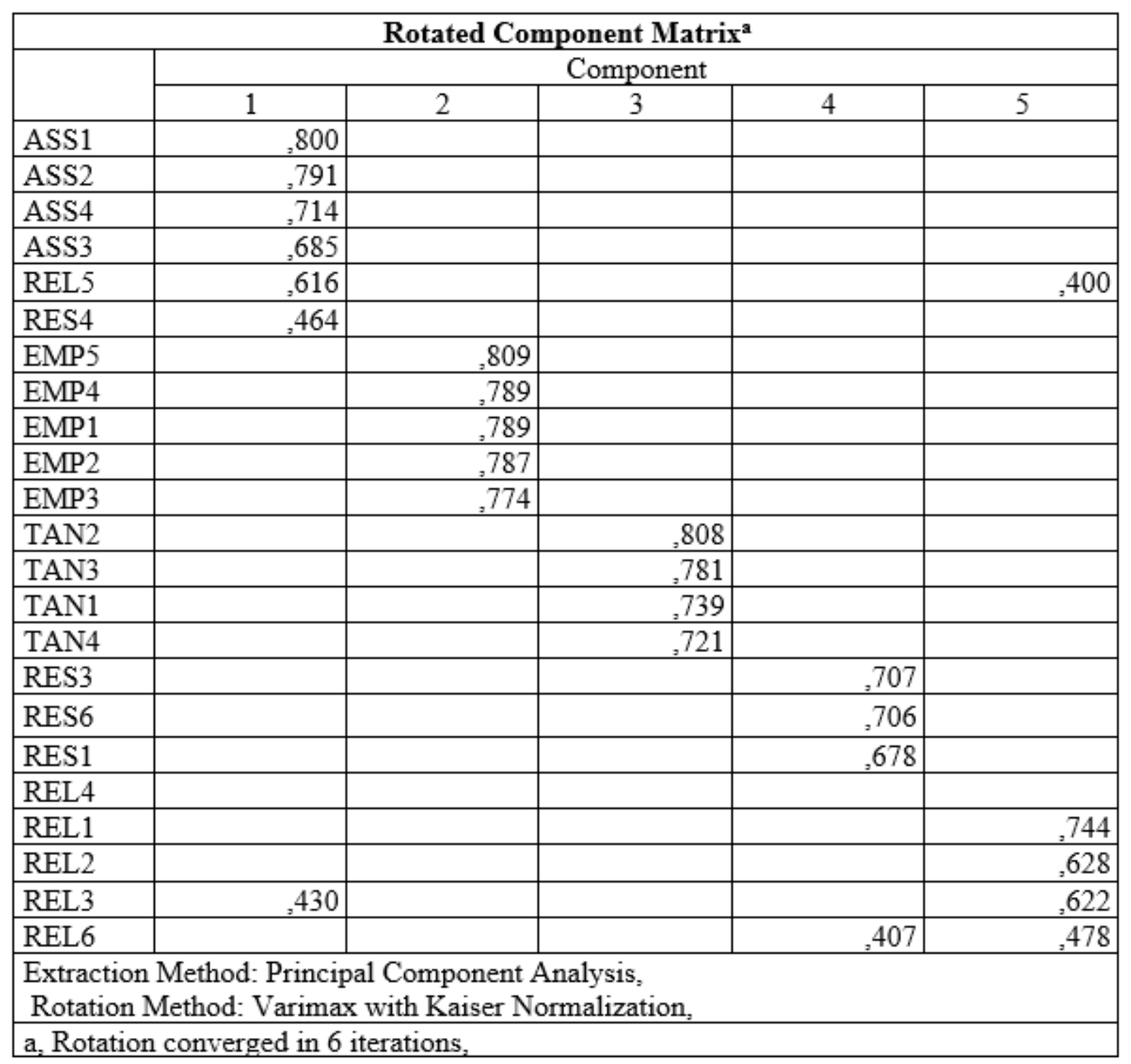


Appendix 4: Rotated Component Matrix EFA -3

\begin{tabular}{|c|c|c|c|c|}
\hline \multicolumn{5}{|c|}{ Rotated Component Matrix ${ }^{\mathrm{a}}$} \\
\hline & \multicolumn{4}{|c|}{ Component } \\
\hline & 1 & 2 & 3 & 4 \\
\hline EMP5 & 809 & & & \\
\hline EMP2 & ,788 & & & \\
\hline EMP4 & 785 & & & \\
\hline EMP1 & ,785 & & & \\
\hline EMP3 & ,772 & & & \\
\hline ASS2 & & 807 & & \\
\hline ASS1 & & 804 & & \\
\hline ASS4 & & ,744 & & \\
\hline ASS3 & &, 695 & & \\
\hline RES4 & & .456 & & 611 \\
\hline TAN2 & & & 810 & \\
\hline TAN3 & & & 790 & \\
\hline TAN1 & & & ,749 & \\
\hline TAN4 & & &, 731 & \\
\hline RES1 & & & & 700 \\
\hline RES3 & & & &, 651 \\
\hline RES6 & & & &, 650 \\
\hline REL1 & & & .422 &, 581 \\
\hline REL2 & & & & \\
\hline $\begin{array}{l}\text { Extract } \\
\text { Rotati }\end{array}$ & $\begin{array}{l}\text { rincipal } \\
\text { rimax wi }\end{array}$ & $\begin{array}{l}\text { nt Analys } \\
\text { Normali }\end{array}$ & on, & \\
\hline
\end{tabular}

